\title{
THE THREE BRITISH OCCUPATIONS OF POTCHEFSTROOM DURING THE ANGLO- BOER WAR 1899-1902
}

\author{
Prof Gert van den Bergh \\ Research Associate, Subject Group History and Ancient \\ Culture, North-West University
}

\section{Introduction}

In the course of 1900, the second year of the Anglo-Boer War, Potchefstroom was occupied three times by British forces and twice evacuated, all in the space of five months. This article focuses on the circumstances leading to these events, their significance for the effective British occupation of south-western Transvaal and on the effects of the occupations on the civilian population of the town.

Possession of Potchefstroom, next to Pretoria and Johannesburg, the most populous town in the Transvaal, was a pre-requisite for British occupation of all of the south-western quarter of the Transvaal. The main consideration being that the Western Railway line ran through Potchefstroom terminating in Klerksdorp. Its use was indispensable as a supply route for all garrison towns to be established south and west of Krugersdorp. The expectations that all would be accomplished with ease were dashed by the advent of the guerrilla phase of the war by mid-1900. Critical in this regard was the activation of renewed Boer hostilities securely based in the Gatsrand from where all rail and road communication between Potchefstroom and its supply base in Krugersdorp was disrupted. These factors and other considerations resulted in six months of failed British attempts to secure Potchefstroom.

Alternating Boer and British control of the town had interesting repercussions for the civilian population with its considerable British element leading to a division of loyalty toward the combatants.

After the Sand River Convention of 1852 had normalised relations between the Transvaal and Britain large numbers of British traders settled in Potchefstroom. By 1865 one in six inhabitants were foreigners, mostly British. ${ }^{1}$ An incomplete and

\footnotetext{
${ }^{1}$ The Transvaal or South African Republic. The Transvaal Argus, 5/6/1865.
} 
unofficial census in 1880 indicated that the ratio was closer to one in four. ${ }^{2}$ By 1880 the largest trading establishments in the town were controlled by Britons and a sprinkling of other nationalities, making Potchefstroom the primary economic focal point of the interior of Southern Africa outside of the British Colonies. The trading pre-eminence of Potchefstroom was only lost after the rise of Johannesburg.

In Potchefstroom the tolerant social and political relations that were established over four generations of inter-dependence were disturbed by the Transvaal War of 1880-1881 and seriously disrupted by the spilling over of the Uitlander tensions on the Rand in the nineties, gathering pace as the Anglo-Boer War loomed. ${ }^{3}$ On the eve of the war many British residents, whose loyalties were with the British, left but a sizable number of them were allowed to remain provided their behaviour was orderly. ${ }^{4}$ British occupation of the town within eight months of the outbreak of the war not only relieved them of that obligation, but placing the boot on the other leg. The speed, however, with which control over Potchefstroom fluctuated between British and republican forces from June to November 1900 inevitably emphasised the divergent patriotic tensions.

Mobilisation of the Potchefstroom Commando avoided calling up citizens who were outspokenly pro-British. Seven of the Potchefstromers taken prisoner at Paardeberg, however, had British surnames. ${ }^{5}$

\section{The first occupation}

The initial occupation of Potchefstroom was undertaken by mounted troops of General Bryan Mahon on 11 June 1900, ostensibly as part of the routine pacification of the Western-Transvaal after the occupation of Pretoria. ${ }^{6}$

The British expectation that the end of the war was imminent meant that only a small force was left in Potchefstroom under command of Major Alan Gough. ${ }^{7}$ Any

${ }^{2}$ F. Jeppe. 1991. Transvaal Book Almanac and Directory 1881 (Pietermaritzburg: Davis \& Sons), pp. 246-53.

${ }^{3}$ R. Scorgie. 1971. My Swan Song. Manuscript. Potchefstroom Museum.

${ }^{4}$ National Archives of South Africa. Pretoria. (hereafter NASAPta). ZPO (Landdrost Potchefstroom). 287a. Briewe kopieboek. Siviele Kommissaris, Proklamasie, 28/10/99; ZPO 286. Commissie Rust en Orde. Notuleboek. Kennisgewing 10/09/99; Regulasies, 27/10/99.

${ }^{5}$ Returns of POW Staff Officer. War Museum of the Boer Republics, Bloemfontein.

${ }^{6}$ J.H. Breytenbach. 1996. Die Geskiedenis van die Tweede Vryheidsoorlog Deel V. (Pretoria: Staatsdrukker), p. 253.

7 NASAPta. Lord Roberts Papers (hereafter LRP) Vol. 40. Telegram. General Methuen - Lord Roberts, 01/08/1900, p.2; L.S. Amery (ed). 1906. Times History of the War in South Africa Vol. IV (London: Samson Low), p. 362; M.H. Grant \& F.M. 
expectation that Gough's command would be uneventful was soon disillusioned. The District was yet to witness much military activity.

By that time, British control of the region between Krugersdorp and Klerksdorp rested with General Geoffry Barton, commanding the Military District West of Johannesburg with headquarters in Krugersdorp. ${ }^{8}$ One of Barton's responsibilities was to secure the railway line between Krugersdorp and Potchefstroom. ${ }^{9}$

An unforeseen turn of events was the advent of the guerrilla phase of the war to which the republican leadership reverted after the collapse of conventional resistance. For its conduct in Western Transvaal, commandos were placed under command of Assistant-Commandant-General Koos de la Rey. One of his senior commanders, General Petrus Liebenberg, was charged with organising and leading guerrilla resistance in the Potchefstroom District. ${ }^{10}$ In the words of General Smuts, Liebenberg was destined to create "a pandemonium for his bewildered enemies". His first success was the reoccupation of Klerksdorp on 24 July 1900. Liebenberg found Potchefstroom a tougher nut to crack and contented himself with the less risky option of denying Gough supplies by disrupting rail and road communication with his supply depot at Krugersdorp. Liebenberg ensconced himself in the Gatsrand, a sheltered, well-watered and fertile hilly region north-east of Potchefstroom. ${ }^{12}$ So effective was his control of road and rail routes that Gough soon complained that he was in a state of siege. ${ }^{13}$

Under British occupation, administrative control of Potchefstroom was initially of a military nature. Major Gough was in control of civilian affairs while Captain D.G. Williams was appointed Provost Marshall. Within a month, administrative control became a separate office and passed into the hands of a more senior District

Maurice. 1910. History of the War in South Africa, 1899-1902 Vol. III (London: Hurts and Blackett), pp. 232, 235.

${ }^{8}$ Grant \& Maurice. History of the War Vol. III, p. 232.

${ }^{9}$ L. Creswicke. 1900. South Africa and the Transvaal War Vol. VI (London: Caxton \& Coy), p. 68; Amery. Times History Vol. IV, p. 488.

10 NASAPta. A 313. Generaal J.H. de la Rey Versameling. Herinneringe van generaal J.H. de la Rey, p.49; Band 9. Brieweboek. De la Rey-Kruger, 21/7/00.

${ }^{11}$ S.B. Spies \& G. Nattras (eds). 1994. Jan Smuts. Memoirs of the Boer War (Johannesburg: Jonathan Ball), p. 96.

${ }^{12}$ The Gatsrand is demarcated by the N17 from Potchefstroom to Johannesburg and the R501 to Carletonville and the road linking Carletonville and Fochville.

${ }^{13}$ J.H. Meyer. 1971. Kommando-jare. ' $n$ Oudstryder se persoonlike relaas van die Tweede Vryheidsoorlog (Kaapstad: Human \& Rousseau), pp. 126-31; Grant \& Maurice. History of the War Vol.III, p. 247. 
Commissioner ${ }^{14}$, Lieutenant-Colonel A.H.M. Edwards, whose task was a purely civic one. His priorities included the pacification of the district by accepting the surrender of all men of military age still under arms, demanding from them an oath of neutrality and replacing republican officials by pro-British residents. Edwards' main problem was the lack of food for the townsfolk. Two days after his arrival he reported to the Director of Civil Supplies in Johannesburg that the town was "bordering on starvation," 15 but his appeal for supplies was left unanswered, probably due to the prevailing expectation that the war was close to its end.

Although a conscientious official, Edwards' anti-republican sentiments tended toward extremes. His attitude and actions towards women and children whose menfolk were still on commando were harsh. Their property was declared confiscated and they were sometimes brutalised and threatened with expulsion. ${ }^{16}$

\section{The first evacuation - the first De Wet drive}

The first evacuation of Potchefstroom revolved around what is known as the first De Wet drive in which the Free State Chief Commandant, having escaped from the British entrapment of the bulk of the Free State forces at the Brandwater Basin, was pursued by a large British force in the direction of the Transvaal. Largely due to its embarrassing failure from a British perspective, the drive itself has been thoroughly researched, ${ }^{17}$ while the incidental role of Potchefstroom therein has been overlooked.

The brief focus on Potchefstroom in the month-long drive centres on the role of General Paul Lord Methuen in the Battle of Tygerfontein. The emphasis here is on the events leading up to and the subsequent battle, both for the civilian population and for the burghers still under arms.

Relevant to this article is the fact that strategic considerations of the drive dictated that De Wet first move northward across the Gatsrand to the Magaliesberg and thence eastward to affect a meeting between the two republican Presidents, and for De Wet to meet with General Louis Botha.

\footnotetext{
${ }^{14}$ NASAPta. LRP Vol. 9. Telegrams Methuen - Roberts, 30/06/00, 30/06/00, p. 5.

${ }^{15}$ NASAPta. GG2 (Military Governor, Johannesburg). Incoming Correspondence. Edwards-Director of Military Supplies, 15/06/00.

${ }^{16}$ P. Pienaar \& A.J.J. Ebeling. 1902. Met Steyn en De Wet (Middelburg: Den Boer), pp. 171-2.

${ }^{17}$ The most authoritative study is that of Pretorius, F. 1976. Die eerste dryfjag op hoofkammandant C.R. de Wet. Christiaan de Wet Annale Deel 4 (Bloemfontein: S.A. Akademie vir Wetenskap en Kuns).
} 
By 25 July, De Wet was in the Vredefort Dome close to the Vaal River, where he called an eleven-day stay. By then Liebenberg had been in communication with him from the Gatsrand, his instructions from De La Rey having included supporting De Wet's mission. ${ }^{18}$

Among the many reasons for the disappointing progress made by the British in the drive up to that point was the persistence of the Commander-in-Chief, Lord Roberts, to control the operation from his headquarters in Pretoria and his indecision as to where De Wet was to be given the coup de grace. Was it to be south or north of the Vaal River?

To accomplish the final defeat of the Free Staters a strong force had to be mustered on the Transvaal side. This task was given to Methuen, at that time combating De la Rey in the Magaliesberg. On 23 July 1900, he was ordered to move the greater part of his division to Potchefstroom. ${ }^{19}$ Methuen's instructions were twofold. He was to safeguard the railway from the ravages of Liebenberg ${ }^{20}$ and, based on Roberts' conviction that De Wet intended to occupy Potchefstroom, he was to prevent him from crossing into the Transvaal ${ }^{21}$ and thereby assist in forcing the Free Staters' capitulation. ${ }^{22}$ Harassed by skirmishes with Liebenberg from Welverdiend onward Methuen arrived in Potchefstroom on 30 July.

\section{The Battle of Tygerfontein}

By the beginning of July, Roberts had resolved to defeat De Wet on the Free State side of the Vaal. An infuriating delay in issuing and disseminating orders to this effect was caused by the discovery that the British heliograph code had fallen into Boer hands. Methuen's orders were issued on 27 July, but due to Liebenberg's disruption of communications with Potchefstroom, the instructions did not reach Methuen until 5 August.

Methuen's task was now formulated as preventing De Wet from crossing into the Transvaal. He set out from Potchefstroom on 6 August, almost at exactly the same moment that De Wet began leading his own forces across Schoeman's Drift into the Transvaal.

\footnotetext{
${ }^{18}$ Pienaar. 1902. Met Steyn, p. 102.

${ }^{19}$ NASAPta. South African Telegrams 111. Roberts-Methuen 23/07/00, p. 92.

${ }^{20}$ Grant \& Maurice. History of the War Vol.III, p.342; Creswicke, Transvaal War Vol. VI, p. 69.

${ }^{21}$ NASAPta. A2044. South African Despatches Vol. 2, No. 6. Roberts-Secterary for War. Para. 28, p. 54.

${ }^{22}$ NASAPta. LRP Vol. 9. Telegram Methuen - Roberts, 27 -29/07/00, pp. 3-5.
} 
The Battle of Tygerfontein, ${ }^{23}$ which took place the next day, did not succeed in either defeating the Free Staters, or preventing De Wet from continuing his trek northwards.

On the day after the battle, Methuen sent a convoy of 28 wagons with his wounded back to Potchefstroom. The main purpose of this was to re-supply Methuen from the large quantity of stores, which had been stockpiled at the railway station. ${ }^{24}$ Further orders reached the convoy commander during the night. He was to destroy all supplies, which could not be transported, evacuate the town and rejoin Methuen. ${ }^{25}$

Understandably, the arrival of Methuen had caused much excitement amongst the town's population. For the loyalists it was the cause of jubilation. Not only was it seen as relieving the embattled Gough, saving the town from occupation by Liebenberg, securing the railway and ensuring a regular food supply, but also as intended to establish a secure garrison base in Potchefstroom. The departure of Methuen after a stay of only six days dashed these expectations. The shock was aggravated by the departure, a day later, of the bulk of Gough's troops, followed on the morning of 9 August by the remainder of the garrison and even of Edwards and his staff themselves.

Edwards refuted rumours of the intended evacuation to the last, but on the evening of the $8^{\text {th }}$ Williams summoned the men among the loyal population to the landdrost's office and informed them that, within hours, the last vestige of British occupation was to be terminated. Panic ensued among those whose Union Jack waving a week earlier now seemed over enthusiastic.

A somewhat comical scene was enacted the next morning, this time not at the northern entrance to the town but at the southern exit. A group of some 80 British men, mostly traders, their sons and clerks, formed an appendix to the last British troops marching out. They travelled on horseback, by carts and on foot, carrying only the barest necessities. Some 200 black servants and other "refugees" accompanied them. The procession was bade farewell by jeering republicans on the one hand and by cheers from the remaining loyalists on the other. Edwards described the refugees as townsmen who had thrown in their lot with the British and whose position "was anything but a pleasant one". The cortège wound its way to the

\footnotetext{
${ }^{23}$ For a description of the Battle see Pretorius. Die eerste dryfjag, Chap. 7.

${ }^{24}$ NASAPta, LRP Vol. 40. Telegram. Methuen - Roberts, 08/08/00, p. 8; Vol. 44. Telegrams Smith-Dorien-Roberts, 07/08/00, p. 4; 08/08/00, p. 5.

${ }^{25}$ H.W. Wilson 1902. The South African War. After Pretoria: The Guerrilla War Vol. 1 (London: Amalgamated Press), p. 44.
} 
appointed rendezvous with Methuen and remained a neglected appendix to his troops until the evening of 12-13 August when they reached Frederikstad. There, still under the care of Edwards, and leaving their transport behind, they, together with wounded troops, were entrained for Johannesburg. Edwards appealed to the Imperial Relief Officer in Pretoria to grant them free rations. His argument was that by that time their shops and homes in Potchefstroom were surely plundered by the republicans - an unfounded presumption. He also surmised that hunger and fear prompted their abandoning Potchefstroom. This did not account for the fact that no wives or daughters accompanied them, as no one feared that they might be molested by pro-republicans. ${ }^{26}$

\section{The first Boer re-occupation of Potchefstroom}

On 9 August, on the day the last vestiges of British occupation ended, a group of Liebenberg's burghers entered Potchefstroom, struck the Union Jack at the landdrost's office and hoisted the Vierkleur. Some of Edwards' fears were confirmed when loyalist's stores and homes were searched and a quantity of hidden foodstuffs confiscated. ${ }^{27}$ The Boers were to be left in undisturbed possession of the town for a month. Their re-occupation was nominal, its reality depending on the absence of a British garrison rather than a Boer presence. This was emphasised by the bulk of Liebenberg's commando joining De Wet's trek to the Magaliesberg. Still Liebenberg left enough burgers to continue disruption of the railway as far as Welverdiend to slow down supplies needed for the continuation of the drive. He allowed others to have their horses re-shod in town and those who had families there to visit them. ${ }^{28}$

En route back to the Free State after the drive had been called off, De Wet, with a small group of his burghers and his staff, did indeed stop at Potchefstroom, which Roberts initially thought he intended to do. This time there was no British presence to prevent De Wet from doing so. He arrived around the $25^{\text {th }}$ of August. The reputation of invincibility, which the drive had ensured him, had preceded him. As in Klerksdorp, he held one or more well-attended public meetings on Church Square, encouraging the republicans to keep up the struggle. As a consequence of his own success as much as his rousing speeches, many burghers who had lain down their arms were induced to take them up again and join Liebenberg's commando.

\footnotetext{
${ }^{26}$ Memories of Yesteryear. Evacuation of Potchefstroom during the Anglo Boer War, Potchefstroom Herald, 20/08/1976 ; Scorgie. Swan Song, p 108

${ }^{27}$ Scorgie. Swan Song, p. 115.

${ }^{28}$ Pienaar. Steyn en De Wet, p.171.
} 
An interesting sidelight was the recollection of a nun at the convent school that she was visited by a group of burghers for the purpose of commandeering flour. She took them to inspect her bare larder. Appalled at the distress of the convent, they later brought her a bag of flour. ${ }^{29}$

De Wet left Potchefstroom for the Free State on receiving news of General Hart's approach.

\section{Considerations for the second British occupation}

After the first evacuation Edwards, retaining the title of District Commissioner and still attached to Barton's command, moved to Krugersdorp. To add some vestige of reality to his office monthly administrative budgets for Potchefstroom were still submitted. In fact whereas $£ 800$ had been allotted for August, $£ 1285$ was appropriated for September and all of it spent, despite the entire administration then being in Krugersdorp. The budget provided salaries for lesser civil officials including police, guides and postal service. This might appear trivial, even irrational, but should be seen against the lingering conviction that the end of the war was at hand and that it would inevitably result in the re-occupation of Potchefstroom.

Broad strategic considerations however, dictated a more urgent reoccupation. Control of the town with its rail connection to the Witwatersrand was an indispensable first step in securing control of all of south-western and far-western Transvaal where no firm hold had yet been established.

Any planning for a successful reoccupation of the town had to start with a reappraisal of the role of Potchefstroom and its surroundings in the embarrassing failure of the De Wet drive.

After Methuen's failure to defeat De Wet at Tygerfontein he had hoped to blockade the Free State General in the Gatsrand, but the pursuing forces "kept spinning a spider's web in disorder" ${ }^{30}$ which allowed De Wet to escape over the Gatsrand, the railway line and the Mooi River. Barton's assessment of Methuen's inability to exploit the strategic advantages he commanded at was now brought to focus on Liebenberg's control of the Gatsrand.

It was noted that even before reaching Potchefstroom Methuen was obliged to leave General Horace Smith-Dorien with about a third of his force to protect the railway line and signal communications between the present Carletonville and

29 J.E. Brady. S.A. Centenary of the Catholic Church in Potchefstroom, p. 75. Manuscript. Catholic History Bureau. Johannesburg.

${ }^{30}$ A.C. Doyle. 1902. The Great Boer War (London: Smith, Elder \& Co), p.195. 
Frederikstad from the regular incursions by Liebenberg. Even with such a force and further reinforcements, Smith-Dorien could not cope. He described the region as "a hotbed of Boers" moving about in plain sight, constantly crossing and re-crossing the railway line, shelling his positions, ambushing his patrols and disrupting communications. "The whole country", he complained, "was very much disturbed". Trains bringing indispensable supplies for Methuen required strong escorts to move from one railway station to the next and one such convoy had even been forced to turn back. Their ultimately reaching Potchefstroom depended more on Liebenberg's whims than on Smith-Dorien's control. ${ }^{32}$ So demanding was this task that the General was obliged to inform Roberts that he was unable to keep an eye on De Wet should he come to the Gatsrand, much less to prevent him from crossing it. ${ }^{33}$ His prophetic conclusion was that "only when an adequate force was available could clearing the Gatsrand and closing down on De Wet be affected" ${ }^{34}$

Worrying was Liebenberg's return to his lair in the Gatsrand by the beginning of September after conclusion of the drive and his regaining control over the extensive region stretching from Klerksdorp to Potchefstroom and northwards to include Ventersdorp and the present Fochville and Carletonville. This was exasperated by the well-founded suspicion that Liebenberg had supplied De Wet with food from the Gatsrand and Mooi River farms during his eleven-day stay in the Vredefort dome before crossing into the Transvaal.

\section{The second occupation}

The above considerations indicated that there were three prerequisites for a successful reoccupation of Potchefstroom, namely:

- $\quad$ securing control of the railway line between Welverdiend and Potchefstroom;

- $\quad$ ending Liebenberg's control of the Gatsrand; and

- maintaining a large garrison in Potchefstroom.

The accomplishment of all these tasks was given to General Arthur Hart. He was given command of the Potchefstroom Column, one of four mobile formations

\footnotetext{
${ }^{31}$ NASAPta. LRP Vol. 44. Smith-Dorien-Roberts, 06/08/00, p. 2.

${ }^{32}$ NASAPta. LRP Vol. 44. Telegram Smith-Dorien - Roberts, 06/08/00, p.2; Vol. 10. Telegram. Smith-Dorien - Roberts, 31/09/00, p. 108.

${ }^{33}$ NASAPta. LRP Vol. 44. Telegrams Smith-Dorien - Roberts, 08/08/00, p. 4; 08/08/00, p. 5; 09/08/00, p.6.

${ }^{34}$ Ibid. 06/08/00, p. 2.
} 
designed to combat the new decentralised Boer strategy. ${ }^{35}$ Hart was to use no halfmeasures. His instructions were manifold. Militarily he was to clear the Gatsrand of Liebenberg, reoccupy Potchefstroom and establish a garrison there.

Hart left Krugersdorp on 28 August moving along the railway line to Bank station. From there he commenced his clearing operations by zigzagging across the Gatsrand. ${ }^{36} \mathrm{He}$ first swept eastwards towards the Losberg where his troops witnessed the destruction of the waterworks at Zuurbekom by the resourceful Danie Theron. ${ }^{37}$ Hart then returned to the Mooi River and began a systematic plundering of farms, "clearing this hostile region of its abundant supplies ${ }^{38}$, harassed, as was foreseen by Liebenberg. On 5 September Hart's action, ostensibly against Liebenberg, resulted in the death of Theron.

Two days later, having given up expectations of drawing Liebenberg into a decisive battle, Hart recrossed the Gatsrand westwards, but instead of continuing to Potchefstroom, he moved along the Mooi River in the opposite direction to burn down the settlement at De Beers Kraal.

With Liebenberg shaken off, Hart retraced his steps toward Potchefstroom in a forced march during the night of 9 September aided by a full moon. His mounted infantry and foot soldiers, transported by wagon, arrived at the northern outskirts of the town by sunrise on the $10^{\text {th, }}$ surprising the handful of Boers visiting their families there. $^{39}$

The second British occupation had commenced. It was to be brief. Having achieved this part of his instructions, Hart set about securing communications with Krugersdorp. Two bridges, one just north of the town and the other at Frederikstad, some 25 kilometres farther north, had been damaged in the mean time and required repair. Until this was effected, trains could not reach Potchefstroom and fatigue parties had continually to be sent as far as Welverdiend, 40 kilometres distant, to bring essential supplies into town. Like Gough and Methuen, Hart's failure to dislodge Liebenberg, was to haunt him. Once more patrols leaving the security of the town were involved in skirmishes. Although Hart was obliged to acknowledge that Liebenberg was in complete control of the environs of Potchefstroom, he

\footnotetext{
${ }^{35}$ For the composition of his column see Grant \& Maurice. History of the War Vol.III, p. 375.

${ }^{36}$ NASAPta. A2044. S.A/ Despatches, Vol. 2, No.6. Roberts - Secretary for War, 10/10/00, p. 62.

${ }^{37}$ NASAPta. LRP Vol. 46. Telegram. Hart-Roberts, 01/09/00, p. 3.

${ }^{38}$ Ibid. 03/09/00, p. 2.

${ }^{39}$ Ibid. 13/09/00, pp. 25-8.
} 
endeavoured to draw the enemy into a decisive battle by a series of sorties in all directions.

Rumours that Boer forces were assembled at Frederikstad, or Ventersdorp, or, perhaps Klerksdorp or the mines at Eleazer, had him despatch forces on half a dozen searches. ${ }^{40}$ Whatever truth there may have been in those reports, Liebenberg's scouts gave adequate early warning to avoid contact. Hart compensated for his inability to find and dislodge Boer forces by visiting "ruination" on all the farms he crossed. ${ }^{41}$

As for the civilian population of Potchefstroom, it was now the turn of the British to search the town systematically for men who were suspected of violating their oath of neutrality. Indeed Hart had been instructed by Roberts to regard all males he might encounter, whether armed or not, as brigands and to treat them as prisoners of war. Based on information received from pro-British Potchefstromers, some 70 men and boys of the town were arrested. ${ }^{42}$ Judging from payrolls this information came from two of the town's prominent merchants, Owens and Scorgie. They were listed as intelligence officers, agents and guides. In contrast to the shadow officials who resided in Krugersdorp, these two at least earned their keep. In his report on the operation ${ }^{43}$ Hart also referred to 25 local black "police" in service of the army and for whom provision was made on the September budget. Many of them were spies, but chiefly they were guides and intelligence sources whose main task was to point out sites where arms were buried. Unsalaried, their payment was in proportion to the yield of their information.

Edwards was by this time promoted to district commissioner for the entire region west of Johannesburg. He was succeeded as Commissioner for Potchefstroom by Captain H.B. Sykes, until then his assistant and now promoted to major. Sykes inherited all the commissariat problems of his predecessors. For a start he forbade the provision of any foodstuff to pro-republicans in the town, pointing out that any such provisions would find their way to the commando - a poor surmise as the burghers in the Gatsrand were far better provided than their families in town. Nonethe-less the loyalists in town shared whatever victuals Sykes could provide with

${ }^{40}$ Ibid. 13/09/00, pp. 25-8; 13/09/00, 14/09/00, pp. 34-6; 19/09/00, p. 35.

41 J.P. Brits. (ed). 1974. Diary of a National Scout (Pretoria: Human Sciences Council), p. 8.

${ }^{42}$ NASAPta. LRP Vol. 46, Telegram. Hart -Roberts, 13/09/00, p. 28.

${ }^{43}$ NASAPta. A2044. South African Despatches, Vol 2, No. 6. Roberts-Secretary for war, 10/10/00; LRP. Vol. 54. Telegrams, Hart. Report on Operations, 02/10/00. pp. 92-6. 
their pro-republican neighbours. The opposite was the case when, under Boer occupation, butcher Lombard, refused to sell meat to English residents. ${ }^{44}$

\section{The second evacuation}

Hart's position in Potchefstroom was precarious. Rumours and reports of Boer movements and strengths were unreliable, and he was pressed to contain even the limited torments of Liebenberg. Hart pointed out that he did not have a large enough force both to garrison the town and to conduct operations in the vicinity effectively despite mounted reinforcements having been sent from Krugersdorp. ${ }^{45} \mathrm{He}$ was therefore forced to choose between sweeping the district and effectively occupying the town. In an effort to pursue the first option, he undertook what amounted to an evacuation of Potchefstroom on the $15^{\text {th }}$. His only concession was to leave a small force in town while he devoted all his efforts to chasing phantom Boer forces as and where rumours indicated their camps or movements to be. In no instance did he achieve more than spotting their distant dust. ${ }^{46}$

Disillusioned by Hart's lack of success, Roberts, who now held him in low esteem, ${ }^{47}$ recalled him to Krugersdorp on 22 September. The order, delivered by a black messenger as the telegraph line had been cut again, reached Hart some days later at Eleazer Mine where he was contemplating the ashes left smouldering at one of Lienbenberg's campsites. ${ }^{48}$ No doubt relieved by the order Hart started off immediately and was back in Krugersdorp on the $30^{\text {th }}$ after an absence of 33 days.

In retrospect, Lord Roberts, still believing that the war was over, intended the task of the Flying Columns to be limited to policing, ${ }^{49}$ but Amery, writing soon after the war, attributes Hart's failure to the composition of the columns. The troops, he maintains, "were nothing but escorts to their supply columns... the British walked where they liked, and the Boers rode where they pleased"50 - the experience of Smith-Dorien and Hart exactly.

\footnotetext{
${ }^{44}$ Scorgie. Swan Song, p. 111.

${ }^{45}$ NASAPta. LRP Vol. 46. Telegram. Hart-Roberts, 03/09/00, p. 3.

${ }^{46}$ Ibid. 19/08/09/00, pp. 42-4.

47 NASAPta. A2044. Confidential Telegrams Vol. 1. File 300, Roberts-State Secretary of War, p. 190.

${ }^{48}$ NASAPta. LRP Vol. 46. Telegram. Hart-Roberts, 27/09/00, p. 48; 29/09/00, p. 63.

${ }^{49}$ NASAPta. A2044. South African Despatches. Vol 2. Roberts. Circular, 25/08/00.

${ }^{50}$ L.S. Amery. 1907. The Times History of the War in South Africa Vol. V (London: Samson Low), p. 5.
} 
On returning to Krugersdorp Hart was again engaged by the gnawing Liebenberg to such an extent at Frederikstad that, on the 18th he ordered the small garrison left in Potchefstroom to join him. After that, the only remaining vestige of his having been there was a "warning notice... that he intended to return... and will exact penalties for disloyalty". 51

By the time he reached Krugersdorp he claimed to have been engaged in no less than 29 skirmishes, mostly with Liebenberg. ${ }^{52}$ This figure seems vastly exaggerated and must have included sightings of dust and abandoned bivouacs. The only prizes he could show were 96 prisoners, mostly boys and old men few of whom were militarily active. His other prisoners were nine women and their children, relatives of Griqualand-West rebels who had been living in Potchefstroom since the collapse of the Boer offensive in the Northern Cape Colony some months earlier. Hart described them as "viragoes" and "furies", the "terror of the loyal families" in Potchefstroom..$^{53}$

In all other respects his efforts to mop up, what Roberts had described as the "remaining scattered forces" of the enemy in the district, had miscarried.

The pro-British civilians still in Potchefstroom - Hart estimated them at some 400 - were relatives of the men who had fled the town after Methuen had left. Those remaining had hoped that their menfolk would be returning following Hart's reoccupation. The opposite was to happen. On 13 September, two days before his evacuation, again following rumours of what was to come, Hart was approached by the loyalists pleading to be "themselves removed or relieved" for fear of hunger and Boer reprisal. Sykes, in the spirit of his mentor, Edwards, little more than a month earlier, passionately protested the second withdrawal. He argued that British prestige would suffer an incalculable setback if loyalists in Potchefstroom were to be delivered into Boer control for a second time. Methuen's coming could be seen as incidental and his departure as inevitable against the background of a greater strategic objective, but the present occupation was deliberate, indeed exactly aimed at undoing the first evacuation. Like Methuen, Hart sympathised with these views, but placed military requirements above civilian needs. He compromised, on the one hand by permitting townsfolk who wished to do so, to accompany him, and by granting Sykes and his staff permission to remain in Potchefstroom with a small garrison as a sop to the lamentations of the shrinking number of loyalist families. ${ }^{54}$ With all the towns in the district still in Boer hands and no improved prospects of

${ }^{51}$ NASAPta. LRP Vol. 46, Telegram. Hart-Roberts 19/09/99, p. 42.

${ }^{52}$ NASAPta. LRP Vol. 54. Report of Operations, 01/10/00, p. 92.

${ }^{53}$ NASAPta. LRP Vol. 46. Telegram Hart - Roberts, 19/09/00, p. 44.

${ }^{54}$ NASAPta. LRP Vol. 46. Telegram Hart - Roberts, 13/09/00, p. 30. 
keeping railway communication with Krugersdorp open, it is to the credit of Sykes that he accepted a charge fraught with risk.

Those choosing to leave with Hart were to use their own transport. Hart justified taking these, some 250 whites and 150 of their black servants, along by conjuring up the spectre of starvation facing them in Potchefstroom and, less likely, of their being molested by Liebenberg, who was certain to reoccupy the town. The group accompanied the troops to Welverdiend station where they stayed overnight, hearing the battle noise at Frederikstad some 20km away, where Hart was once more clashing with Liebenberg. The next day each family was given a voucher for $£ 25$ in exchange for their wagons. They were then loaded onto open train trucks and taken to Johannesburg to join their menfolk. Hardship awaited them. The meagre rations provided by the Imperial Relief Commission had to be supplemented out of their own pockets. ${ }^{55}$

Liebenberg again entered Potchefstroom unopposed, removed Hart's threatening notice and posted his own, proclaiming the continuation of the struggle for independence. $^{56}$

A third and more urgent effort at occupying Potchefstroom was to come.

\section{Considerations for the third British occupation}

Their inability to secure control of Potchefstroom and the extensive region around it was an embarrassment to the British High Command. Barton and Roberts tended to blame the failure of the second occupation on Hart whose marauding actions in the Gatsrand region, they felt to be inadequate, exposed his soft a nature, which "in this district it is not deserved... the district is thoroughly disturbed... severe penalties and reprisals should be exacted". 57

These opinions expressed by Barton were hardly new. The identification of Liebenberg as a military target and the destruction of the fertile Gatsrand and Mooi River region as objectives were still valid, now emphasised by Hart's failure to deal them a telling blow. Ostensibly the third attempt to resolve the problem had no new purpose. The Liebenberg factor, however, seemed by then to have loomed larger and merits closer scrutiny.

When first sent to the Potchefstroom region by De la Rey at the beginning of June 1900 Liebenberg commanded some 300 burghers of the Potchefstroom

\footnotetext{
${ }^{55}$ Scorgie. Swan Song, p. 112.

${ }^{56}$ Brits. Diary, p. 10.

57 NASAPta. LRP Vol. 52. Telegram. Barton - Military Secretary, 01/10/00, p. 2. Creswicke. Transvaal War Vol. VI, p. 117.
} 
Commando who had escaped the massive surrender at Paardeberg four months earlier. He was accompanied by Jan Smuts, who, in his capacity as State Attorney, had the express task of re-commandeering those burghers of the District who had lain down their arms under whatever circumstances. ${ }^{58}$ Smuts' success is reflected there in that by the time he joined De Wet's force on 11 August Liebenberg's commando had swelled to an estimated 400 to $600 .{ }^{59}$ So active was Smuts that by the end of September Barton was convinced that there was not a single male in the Gatsrand who had not joined Liebenberg. The effect of it all was that no communication, verbal or material, between the commissariat and manpower depot at Krugersdorp and Potchefstroom could be guaranteed. ${ }^{60}$ In the words of General Smuts, "suddenly and unexpectedly the British occupation of the Western Transvaal ended with more dramatic rapidity than it had begun". ${ }^{61}$

As for the farming infrastructure of the Gatsrand and Mooi River, the formal justification for its destruction was that the "Intelligence Department had well described this locality as a depot of supply for Boers still under arms". ${ }^{62}$ Hart, Barton and Roberts were still in agreement that any lasting occupation of Potchefstroom could only be ensured once a sequence of events had occurred. The railway, the "incessant attacks (on which had become) too numerous to be recorded" ${ }^{, 63}$ was to be safeguarded. That, in turn, could only be ensured after the Gatsrand had been pacified and that again depended on Liebenberg being dislodged. ${ }^{64}$

There was a further consideration for a speedy reaffirmation of British control. De Wet, having rested his burghers after the end of the drive, was again active close to the Vaal River. Mindful of the ease with which he had eluded his pursuers during the drive, Barton was also to "check" or "turn" a new excursion of the Free State General into the Gatsrand. ${ }^{65}$

\footnotetext{
58 S.B. Spies \& G. Natrass (eds). Jan Smuts. Memoirs of the Boer War (Johannesburg: Jonathan Ball) p. 85.

${ }^{59}$ NASAPta. LRP Vol. 39. Methuen - Roberts, 28/07/00, p. 189; Leyds Argief. No. 759. Liebenberg -Gen. Botha, 17/08/00, p. 57.

${ }^{60}$ NASAPta. LRP Vol. 52. Barton - Military Secretary, 01/10/00, p. 2.

${ }^{61}$ Spies \& Natrass. Memoirs, pp. 96, 85.

${ }^{62}$ NASAPta LRP Vol. 46. Telegram. Hart - Roberts, 03/09/00, p.11.

${ }^{63}$ Creswicke. Transvaal War Vol. VI, p. 118.

${ }^{64}$ NASAPta. LRP Vol. 52, Telegram. Barton - Roberts, 04/10/00, p. 6.

${ }^{65}$ NASAPta. LRP Vol. 52. Telegram. Barton - Roberts, 11/10/00, p. 26; See also Grant \& Maurice. History of the War Vol .III, p.509.
} 


\section{The third occupation}

Ten days after the return of Hart's column to Krugersdorp, Barton was ordered by Roberts to undertake the third occupation of Potchefstroom himself. He left Krugersdorp on 10 October with a considerable force and, like all previous undertakings in the direction of Potchefstroom, moved along the railway line to facilitate supply.

By the $13^{\text {th }}$ Barton, awaited supplies at Welverdiend. Equally routinely, Liebenberg's guns from the hills, some five kilometres distant, shelled his camp. ${ }^{66}$ Once more skirmishes, telegraph disruption and fruitless drives were the order of the day. ${ }^{67}$

It has been observed that the damage of the railway bridge at Frederikstad had made it unusable and necessitated supplies for the British troops in Potchefstroom to be transported from Welverdiend by wagon past the Liebenberg gauntlet. Due to the tenuous British control over the region the bridge had not been repaired. ${ }^{68}$ When Barton arrived at the bridge by the $17^{\text {th }}$ he called a halt, having determined that the bridge be repaired by sappers from Krugersdorp before continuing to Potchefstroom. Favourable tactical terrain and strong perennial fountains in the nearby Mooi River afforded a secure base from where operations against Liebenberg could be conducted and promised sufficient control over the Gatsrand to counter any movement by De Wet in that region. Everything considered his decision to remain at Frederikstad was a sound one. His position was made the more comforting by the arrival of an additional reinforcements and a trainload of supplies on the $20^{\text {th. }} 69$

Barton's appearance and extended stay at Frederikstad and his obvious objectives held no surprise for Liebenberg. Barton's temporary immobility seemed to offer an ideal opportunity to exchange his own prodding skirmishes for a concerted attack. For this he would require the assistance of De Wet, with whom he had retained communication since the end of the drive.

De Wet was still the main concern of British strategists. Two columns consisting mostly of inexperienced troops were tasked to keep an eye on him and denude the farms in his vicinity of any means of sustaining his burghers. Their senior commander was General Charles Knox of the Colonial Division. De Wet had no

${ }^{66}$ Brits. Diary, p. 15; NASAPta. LRP Vol. 51, Telegram. Barton-Roberts, 15/10/00, p. 34

${ }^{67}$ NASAPta. LRP Vol. 52. Telegram. Barton-Roberts, 17/10/00, p. 38.

${ }^{68}$ Ibid. $17 / 10 / 00$, p. 40; 19/10/00, p. 46; 27/10/00, p. 75.

${ }^{69}$ NASAPta. LRP Vol. 52, Telegram. Barton-Roberts, 17/10/00, p. 40; 19/10/00, p. 46; Amery. Times History Vol. V, p. 10. 
difficulty in eluding these watchdogs, easily setting them onto false trails. He crossed the Vaal and made his appearance at Frederikstad on the afternoon of 20 October, overpowering patrols of the surprised Barton along the way.

Thus the surmise of a new De Wet incursion into the Transvaal was justified, but the expectation that Barton was to stop him was reversed. It was De Wet who intended stopping Barton from proceeding to Potchefstroom.

\section{The Battle of Frederikstad}

Details of the Battle, which lasted intermittently from 20 to 25 October, are not relevant here. ${ }^{70}$ The lasting effects of the resounding Boer defeat are.

After the battle De Wet once more disappeared into thin air. For Liebenberg the outcome was more immediate. The Potchefstroom commando suffered the heaviest losses since Paardeberg on the fateful final day of the battle. Liebenberg's success thus far had rested on sound guerrilla tactics, disrupting enemy movements and communications. His rash switch to offensive action on a well-prepared enemy position was catastrophic and resulted in making his control of the Gatsrand untenable. His defeat forced him to move the bulk of his commando away from his old stronghold to the Klerksdorp vicinity.

For Barton the way to Potchefstroom was ultimately clear, not so much by his own merits as by rare poor judgement on the part of De Wet and Liebenberg. It was, however, not Barton who occupied the town, but elements of Knox's Colonial Division under Colonel Hare who arrived in Potchefstroom on 26 October, still looking for De Wet. Barton's main force remained at Frederikstad to be rested and await the arrival of sappers to repair the bridge before returning to Krugersdorp. ${ }^{71}$

British civil administration, having lived in the shadows at Krugersdorp, once more became a reality.

The reoccupation of the town, securing of the railway and expulsion of Liebenberg, did little to relieve the task of the returned Williams and Sykes. As a final show of defiance they were intercepted along the way by a Boer patrol on 30 October and forced temporarily to return to Frederikstad. ${ }^{72}$

\footnotetext{
${ }^{70}$ For details see Grant \& Maurice. History of the War Vol. III, p. 509-12. For a brief recent account which also utilises Boer documents see G.N. van den Bergh. 1994. 24 Battles and Battlefields of the Northwest Province (Potchefstroom: SATOUR), Ch. 13; Also Brits. Diary, pp. 17-20.

${ }_{71}^{71}$ NASAPta. LRP Vol. 52. Telegram Barton-Roberts, 29/10/00, 29/10/00, p. 82.

${ }^{72}$ Ibid. 30/10/00, pp. 90-1.
} 
A prime requirement now was to return the pro-British residents, who had been evacuated to Johannesburg and whose upkeep was at the expense of the army. The fear they entertained that their homes and shops would have been plundered was moderately justified. They were themselves convinced, however, that the real culprits were British soldiers. ${ }^{73}$

The main concern of Sykes was still supplying provisions for the civilian population. In December 38 ladies complained that their weekly ration of $2.25 \mathrm{~kg}$ flour was insufficient for their starving children. Securing an adequate food supply was countered by the opening of the concentration camp with up to 4000 inmates within weeks after the occupation.

For the town's republicans a lean time lay ahead. Civilian police, for whom the provision had been made on the Civil Commissioner's budget, were employed to affect a number of arrests based on accusations by pro-British residents. ${ }^{74}$ Warrants against people living outside the town still proved to be too risky to implement.

For Liebenberg the tide had turned. The British attempts to dislodge him had eventually succeeded. Small groups of burghers still held refuge in the Gatsrand and remained enough of a threat to necessitate the establishment of permanent British garrisons at Welverdiend and Frederikstad. ${ }^{75}$ For the remainder of the war the Potchefstroom Commando's contribution to the republican war effort was concentrated in the equally hilly terrain north and west of Klerksdorp where, joined by other commandos Liebenberg was under the direct command of De la Rey. Liebenberg had established himself as a successful guerrilla leader, but in the company of more experienced and talented commanders he never again attaining the recognition he had enjoyed in the Gatsrand.

The third British occupation of Potchefstroom lasted from 30 October till the end of the war. It served as a base for the reoccupation of Klerksdorp, Ventersdorp and towns farther to the west. The Western Transvaal commandos, sometimes with success, often disputed occupation of these lesser centres but Potchefstroom was never again to be wrested from British control.

\footnotetext{
${ }^{73}$ Scorgie, Swan Song, p. 115.

${ }^{74}$ Ibid. p. 117.

${ }^{75}$ G.F. Gibson. 1937. The Story of the Imperial Light Horse in the South African War 1899-1902 (London: G.D. \& Co), p. 241.
} 